\title{
Weed management during and after rhizoma perennial peanut establishment ${ }^{1,2}$
}

\author{
María de L. Lugo-Torres ${ }^{3}$, Teodoro M. Ruiz' \\ and Raúl Macchiavelli ${ }^{5}$
}

J. Agric. Univ. P.R. 94(1-2):111-119 (2010)

\begin{abstract}
A field study was conducted to evaluate the effect of dimethenamid and imazethapyr followed by clethodim and bromoxynil, on rhizoma perennial peanut (Arachis glabrata) during and after establishment. There were no significant differences in any of the parameters measured among rhizoma perennial peanut accessions as a result of the effects of herbicides. Excellent grass control was obtained when dimethenamid (preemergence) at 1.68 and $3.36 \mathrm{~kg}$ ai/ha was applied during the first month as compared with the use of imazethapyr. At 26 weeks after herbicide application (WAH) excellent grass control was obtained in all herbicide treatments. At 52 WAH no differences were observed for broadleaf and grass density. No differences were detected for dry weight of rhizoma perennial peanut and weeds among herbicide treatments at the 26- and 52-WAH harvests. Plots receiving imazethapyr as an early postemergence (POE) had $44 \mathrm{~g} / \mathrm{m}^{2}$ more dry weight of weeds than plots with dimethenamid at the lowest rate, but no differences were found among the other treatments. The lowest weight of rhizoma perennial peanut was with imazethapyr early POE, as compared with the three other herbicide treatments. No difference was observed with dimethenamid at either rate. After two years, density of broadleaves was the highest (55.6 plants per square meter) with imazethapyr applied early POE. Density of grasses was lower with imazethapyr preemergence and dimethenamid at a lower rate than with the other two herbicide treatments. Overall, taking into account all rates and dates of herbicide applications, the best weed control was obtained with the early application dates.
\end{abstract}

Key words: rhizome perennial peanut establishment, herbicides, weeds

RESUMEN

Manejo de malezas durante y después del establecimiento de maní perenne

${ }^{1}$ Manuscript submitted to the Editorial Board 17 September 2009.

${ }^{2}$ This study was supported in part by the USDA-CSREES special grant Tropical/Subtropical Agriculture Research (T-STAR) administered by the Caribbean Advisory Group. We thank technical support personnel who have assisted with this project, including Héctor Torres and Carlos Almodóvar.

sProfessor, Department of Crops and Agroenvironmental Sciences, College of Agricultural Sciences, Agric. Exp. Station, PO Box 1306, Gurabo, PR 00778.

${ }^{4}$ Professor, Department of Animal Science, College of Agricultural Sciences, Agricultural Experiment Station. Univ. of Puerto Rico-Mayagüez Campus.

${ }^{5}$ Professor, Department of Crops and Agroenvironmental Sciences, College of Agricultural Sciences, Univ. of Puerto Rico-Mayagüez Campus. 
Se estableció un experimento de campo para evaluar el efecto de dimethenamid e imazethapyr seguido de clethodim y bromoxynil en maní perenne (Arachis glabrata), en y durante el establecimiento del mismo. No hubo diferencias significativas entre las variedades de maní perenne para el efecto de herbicida en ninguno de los parámetros medidos. Se obtuvo un excelente control de gramíneas con dimethenamid a 1.68 y $3.36 \mathrm{~kg}$ ia/ha el primer mes después de la aplicación en comparación con la aplicación de imazethapyr. A las 26 semanas después de la aplicación de los herbicidas se obtuvo excelente control de gramíneas con todos los tratamientos de herbicidas. A las $\mathbf{5 2}$ semanas después de la aplicación no hubo diferencias en la densidad de malezas de hoja ancha ni de gramíneas en ninguno de los tratamientos de herbicidas. No hubo diferencias en el peso seco del maní ni en el de malezas entre los tratamientos de herbicidas a las 26 y 52 semanas después de la aplicación. El peso seco de las malezas que recibieron imazethapyr postemergente temprano fue $44 \mathrm{~g} / \mathrm{m}^{2}$ mayor que el de las malezas que recibieron dimethenamid a la dosis menor, pero no se observó diferencias entre los otros tratamientos. El menor rendimiento del maní perenne se obtuvo con la aplicación de imazethapyr postemergente temprano. Después de dos años de establecido, imazethapyr aplicado postemergente temprano produjo la mayor densidad de malezas de hoja ancha, con $\mathbf{5 5 . 6}$ plantas por metro cuadrado. La densidad de gramíneas fue menor con imazethapyr preemergente y con dimethenamid a la dosis de $1.68 \mathrm{~kg}$ ia/ha que con los otros dos tratamientos. En general, las aplicaciones de los herbicidas de forma preemergente resultaron en mayor rendimiento del maní perenne.

Palabras clave: establecimiento de maní perenne, herbicidas, malezas

\section{INTRODUCTION}

Beef and dairy commodities are among the most economically important agricultural activities throughout the Caribbean Islands of the United States. Thus, there is considerable interest in this area to improve both production and quality of forages. Rhizoma perennial peanut (Arachis glabrata) is currently being considered in the Caribbean as an alternative forage because of its low requirements for nitrogen fertilization, relatively high protein content, adaptability to contrasting ecological areas, and low susceptibility to pests (Ruiz et al., 2000; Valencia et al., 1997, 1999). Studies and field observations, however, have shown that rhizoma perennial peanut is a poor competitor against weeds during establishment because of its slow rate of establishment. Therefore, intensive management strategies, such as chemical weed control, must be employed to offset the slow establishment rate (Venuto et al., 2000). A competition-free growing zone promotes above- and below-ground plant development, which in turn shortens the time period to complete establishment (French et al., 2001). Canudas et al. (1989) and Ruiz et al. (2000) reported that when both grass and broadleaf weeds were controlled in the first year after planting, ground cover of the rhizoma perennial peanut was faster.

On the basis of their ability to control weeds in legume forages, both imazethapyr and dimethenamid appear as candidate herbicides to be 
used for reducing early interference immediately after planting rhizome perennial peanut. Imazethapyr is a postemergence selective herbicide that has been labeled for use in alfalfa (Medicago sativa) (Dahmer, 1995). This herbicide gives excellent control of annual grasses and broadleaf weeds. Some short-term stunting of alfalfa plants, however, can occur, but this stunting does not lead to phytotoxic effects before harvest time (Zollinger and Meyer, 1996). Butler et al. (2006) used imazethapyr at $0.07 \mathrm{~kg}$ ai/ha with acetachlor at $2.7 \mathrm{~kg}$ ai/ha pre-planting incorporated (PPI) for perennial peanut establishment plots, and no negative effect or phytotoxicity was observed. Another preemergence herbicide, dimethenamid, is used in peanut (Arachis hypogea) production and, in combination with other preemergence herbicides, is excellent for controlling annual grasses and broadleaf weeds (Jordan, 2007). Clethodim and bromoxynil are grass and broadleaf herbicides, respectively, used in forage and established legumes. We need to identify the best herbicides for the effective establishment of rhizoma perennial peanut as a forage or hay crop. The response of weeds and rhizoma perennial peanut to imazethapyr and dimethenamid in tropical and sub tropical conditions is unknown. The objective of this study was to evaluate strategies to control weeds during and after rhizoma perennial peanut establishment.

\section{MATERIALS AND METHODS}

A field experiment was established in May 2003 at the Agricultural Experiment Station of the University of Puerto Rico in Juana Díaz. At the experimental site, the soil was San Antón series (Cumulic Haplustolls, fine-loamy, mixed, isohyperthermic) with a $\mathrm{pH}$ of 7.7. Cultivar Henorico (Ruiz et al., 2007) and one accession of rhizome perennial peanut USDA 17095 were used. Plot size was $4.6 \mathrm{~m} \times 6.0 \mathrm{~m}$ and consisted of five rows $0.80 \mathrm{~m}$ apart. Planting material was freshly dug rhizomes that were planted continuously within the rows at about a $10-\mathrm{cm}$ depth. Herbicide treatments were 1) imazethapyr at $0.070 \mathrm{~kg}$ ai/ha, preemergence (PRE); 2) imazethapyr at $0.070 \mathrm{~kg}$ ai/ha early postemergence (early POE, applied 16 days after planting); 3) dimethenamid at $1.68 \mathrm{~kg}$ ai/ha - PRE; and 4) dimethenamid at $3.36 \mathrm{~kg}$ ai/ha - PRE. Preemergence herbicide treatments were applied the day after planting (DAP). A portable $\mathrm{CO}_{2}$-pressured backpack sprayer delivering 187 $\mathrm{L} / \mathrm{ha}$ was used for the four treatments. Treatments were arranged in a randomized complete block design with four replications. To ensure plant survival and avoid plant stress, the experimental area was irrigated uniformly the day after the preemergence herbicide treatments were applied. Irrigation was provided by raised sprinklers. 
After the application of herbicide treatments, and to complete weed management until rhizome perennial peanut establishment, we applied uniformly to the plots bromoxynil at $0.28 \mathrm{~kg}$ ai/ha at four, eight and 11 weeks after planting (WAP), and clethodim at $0.28 \mathrm{~kg}$ at 4,11 , 24,31 WAP. At week 42 after planting, a mix of glyphosate and water at $20: 1$ rate was applied with a weed wiper adjusted to $40 \mathrm{~cm}$ above the ground.

Weed composition and density, phytotoxicity to rhizome perennial peanut and dry weight of rhizome perennial peanut were evaluated four, 26 , and 52 weeks after herbicide application. Weed density was estimated from four randomly placed quadrats $\left(0.093 \mathrm{~m}^{2}\right)$ in each plot. Two years after planting, in order to standardize plant height, plants of all plots were cut back to ground level. At seven and 13 weeks after the leveling cut (WAL), relative yield among plots was estimated by obtaining dry weight of rhizome perennial peanut contained in three $0.09 \mathrm{~m}^{2}$ quadrats per plot. For sampling, rhizoma perennial peanut and weeds were cut at ground level. Weeds were counted and identified. Dry weight of weeds and rhizoma peanut was determined after drying the vegetative material in an oven at $60^{\circ} \mathrm{C}$. All data were subjected to analysis of variance, by using a factorial model with treatment, accession, and date effects and their corresponding interactions. Since the observations of differences for both years were taken on the same plot, a repeated measures model was used. Means were separated by using the Tukey's test at the 0.05 significance level.

\section{RESULTS AND DISCUSSION}

Predominant weeds found were horse purslane (Thrianthema portulacastrum L.), wild poinsettia (Euphorbia heterophylla L.), common purslane (Portulaca oleracea L.), junglerice [Echinochloa colona (L.) Link], and purple nutsedge (Cyperus rotundus L.). Slight crop injury was recorded after one week of the second bromoxynil application, but rhizoma perennial peanut recovered and no injury symptoms were noticed at 12 WAP (data not presented). Since throughout the establishment of the rhizome perennial peanut there were no significant differences between accessions nor interactions, treatment means were compared.

\section{Weed density}

Four weeks after initial herbicide application, the density of broadleaves was higher (135 plants per square meter) with imazethapyr applied early POE than with imazethapyr applied PRE (24 plants per square meter) (Table 1). At the time of an early post application, horse 
TABLE 1. Weed density in rhizoma perennial peanut on three reading dates after establishment at Juana Diaz, Puerto Rico, under varying herbicide treatments.

\begin{tabular}{|c|c|c|c|c|c|c|c|}
\hline \multirow[b]{2}{*}{ Herbicide Treatment } & \multirow{2}{*}{$\frac{\text { Rate }}{\mathrm{kg} \text { ai/ha }}$} & \multicolumn{2}{|c|}{$4 \mathrm{WAH}^{1}$} & \multicolumn{2}{|c|}{26 WAH } & \multicolumn{2}{|c|}{$52 \mathrm{WAH}$} \\
\hline & & Broadleaves ${ }^{2}$ & Grasses $^{2}$ & Broadleaves & Grasses & Broadleaves & Grasses \\
\hline Imazethapyr PRE ${ }^{3}$ & 0.07 & $24 \mathrm{a}^{4}$ & 61 & $17 \mathrm{a}$ & $0 \mathrm{a}$ & 39 a & $55 \mathrm{a}$ \\
\hline Imazethapyr - early $\mathrm{POE}^{3}$ & 0.07 & $135 \mathrm{~b}$ & 67 & $22 \mathrm{a}$ & $0 \mathrm{a}$ & $55 \mathrm{a}$ & $111 \mathrm{a}$ \\
\hline Dimethenamid - PRE & 1.68 & $46 \mathrm{ab}$ & 1 & $15 \mathrm{a}$ & $0 \mathrm{a}$ & $14 \mathrm{a}$ & $19 \mathrm{a}$ \\
\hline Dimethenamid - PRE & 3.36 & $72 \mathrm{ab}$ & 0 & $15 \mathrm{a}$ & $0 \mathrm{a}$ & 19 a & $45 \mathrm{a}$ \\
\hline
\end{tabular}

${ }^{1} \mathrm{WAH}=$ weeks after herbicide application.

${ }^{2}$ Broadleaves present were horse purslane (Thrianthema portulacastrum), wild poinsettia (Euphorbia heterophylla), and common purslane (Portulaca oleracea). Grasses and nutseges present were jungle rice (Echinochloa colona) and purple nutsedge (Cyperus rotundus).

${ }^{s} \mathrm{PRE}=$ preemergence; early $\mathrm{POE}=$ early postemergence.

${ }^{4}$ Means within a column followed by the same letter are not significantly different according to Tukey's $(\alpha=0.05$ significance level). 
purslane was the most commonly found broadleaf weed, having a growth stage of more than 10 leaves, all of which resulted in a reduced effectiveness of the treatment. No difference was observed for dimethenamid at either rate of application. During the four weeks, grasses were more effectively reduced with dimethenamid at both rates than with imazethapyr (Table 1). Lower grass control by imazethapyr was related to the reduced control over junglerice.

At $26 \mathrm{WAH}$, all plots had received three applications of bromoxynil and clethodim. When broadleaf density was evaluated at this stage, no differences were observed among herbicide treatments (Table 1). The average density of broadleaves at this stage was 19 plants per square meter. Excellent grass control was obtained in all treatments. Weed control at this stage of the growing season was the result of the effect of the treatments combined with the other management practices, such as the use of additional herbicides, and the stage of development of the rhizome perennial peanut. At $52 \mathrm{WAH}$ no differences were observed for broadleaf and grass density, which averaged 32 and 58 plants per square meter, respectively.

\section{Dry weight of weeds and rhizoma perennial peanut yield}

Differences were detected for dry weight of rhizoma perennial peanut and for weeds among herbicide treatments (Table 2). Those plots receiving imazethapyr as an early postemergence had $44 \mathrm{~g} / \mathrm{m}^{2}$ more dry weight of weeds than plots with dimethenamid at the lowest rate (Table 2). No significant differences were found among the other treatments. The lowest weight of rhizoma perennial peanut was with imazethapyr early POE as compared with the three other herbicide treatments. No difference was observed due to rate of dimethenamid application.

TABLE 2. Dry weight of rhizoma perennial peanut and weeds during the establishment at Juana Díaz, Puerto Rico, 2003-20041.

\begin{tabular}{lcccc}
\hline & Rate & & Dry weight of peanut & Dry weight of weeds \\
\cline { 2 - 3 } \cline { 5 - 5 } Herbicide Treatment & $\mathrm{kg}$ ai/ha & & $\mathrm{g} / \mathrm{m}^{2}$ & $\mathrm{~g} / \mathrm{m}^{2}$ \\
\hline Imazethapyr PRE & 0.07 & & $204 \mathrm{a}^{3}$ & $55 \mathrm{ab}$ \\
Imazethapyr - early POE & 0.07 & & $93 \mathrm{~b}$ & $77 \mathrm{a}$ \\
Dimethenamid PRE & 1.68 & & $286 \mathrm{a}$ & $33 \mathrm{~b}$ \\
Dimethenamid PRE & 3.36 & $203 \mathrm{a}$ & $64 \mathrm{ab}$ \\
\hline
\end{tabular}

${ }^{1}$ Data average of 26 and 52 weeks after planting.

${ }^{2} \mathrm{PRE}=$ preemergence; early $\mathrm{POE}=$ early postemergence.

${ }^{3}$ Means within a column followed by the same letter are not significantly different according to Tukey's ( $\alpha=0.05$ significance level). 
As expected, dry weight of rhizoma perennial peanut across herbicide treatments increased with an increase in time of harvesting (Table 3). Even with the use of herbicides throughout the season, weed dry weight increased $33 \%$ from $26 \mathrm{WAH}$ to $52 \mathrm{WAH}$ (Table 3). Similar results for RPP establishment were reported by Ruiz et al. (2000), where an initial application of a preemergence herbicide, followed by a postemergence application two to four weeks post-planting, appears necessary for initial establishment.

\section{Weed density after two years of establishment}

No interaction was detected between harvest date and RPP cultivar for weed density; therefore, the effect of herbicide treatments was the only one discussed in the analysis. Density of broadleaves was highest (55.6 plants per square meter) with imazethapyr applied early POE (Table 4). Even with the later application of glyphosate, horse purslane was not tall enough to be reached by the wiper application and was the most common weed found. Density of grasses was lower for imazethapyr PRE and dimethenamid at the lower rate than for the two other herbicide treatments. There was not a clear relationship between weed control and weed density in these treatments. Trends in total weeds were influenced largely by density of broadleaves (Table 4).

Weed dry weight and rhizoma perennial peanut yield after two years of establishment

Differences were detected for dry weight of weeds among herbicide treatments at 7 and 13 WAL harvests (Table 5). Plots receiving imazethapyr as an early POE had the highest weight of weeds, but no differences were found among the other treatments (Table 5). As expected, two years after planting, rhizoma perennial peanut yield was

TABLE 3. Dry weight of rhizoma perennial peanut and weeds across herbicide treatments during the first year of establishment at Juana Diaz, Puerto Rico, 2003-2004.

\begin{tabular}{|c|c|c|}
\hline & \multicolumn{2}{|c|}{ Dry weight } \\
\hline & peanuts & weeds \\
\hline & $\mathrm{g} / \mathrm{m}^{2}$ & $\mathrm{~g} / \mathrm{m}^{2}$ \\
\hline $26 \mathrm{WAH}^{1}$ & $143 \mathrm{a}^{2}$ & $46 a$ \\
\hline $52 \mathrm{WAH}$ & $250 \mathrm{~b}$ & $69 \mathrm{~b}$ \\
\hline
\end{tabular}

${ }^{1} \mathrm{WAH}=$ weeks after herbicide application.

${ }^{2}$ Means within a column followed by the same letter are not significantly different according to Tukey's ( $\alpha=0.05$ significance level). 
TABLE 4. Weed density after two years of rhizoma perennial peanut establishment at Juana Diaz, Puerto Rico, on 2005.

\begin{tabular}{|c|c|c|c|c|}
\hline \multirow[b]{2}{*}{ Herbicide Treatment } & \multirow{2}{*}{$\begin{array}{c}\text { Rate } \\
\mathrm{kg} \text { ai/ha }\end{array}$} & \multicolumn{3}{|c|}{ Weed density ${ }^{1}$ (plants $/ \mathrm{m}^{2}$ ) } \\
\hline & & Broadleaves & Grasses & Total \\
\hline Imazethapyr PRE ${ }^{2}$ & 0.07 & $16 \mathrm{a}^{3}$ & $2 \mathrm{a}$ & $18 \mathrm{a}$ \\
\hline Imazethapyr - early POE & 0.07 & $56 \mathrm{~b}$ & $7 \mathrm{~b}$ & $63 \mathrm{~b}$ \\
\hline Dimethenamid PRE & 1.68 & $6 \mathrm{a}$ & $1 \mathrm{a}$ & $7 \mathrm{a}$ \\
\hline Dimethenamid PRE & 3.36 & $11 \mathrm{a}$ & $7 \mathrm{~b}$ & $17 \mathrm{a}$ \\
\hline
\end{tabular}

${ }^{1}$ Broadleaves: Wild bush bean (Macroptilium lathyroides), wild poinsettia (Euphorbia heterophylla), common purslane (Portulaca oleracea), horse purslane (Thrianthema portulacastrum), spurge (Chamaesyce hyssopifolia), wire weed (Sida acuta), gale of the wind (Phylanthus niruri), morning glory (Ipomoea tiliaceae), sensitive plant (Mimosa pudica), sow-thistle (Sonchus oleraceous), Galinsoga spp., small spider flower (Cleome gynandra) and nutsedges (Cyperus spp.); Grasses: jungle rice (Echinochloa colona), large crabgrass (Digitaria sanguinalis), goosegrass (Eleusine indica), and itchgrass (Rottboellia cochichinensis).

${ }^{2} \mathrm{PRE}=$ preemergence; early $\mathrm{POE}=$ early postemergence.

${ }^{3}$ Means within a column followed by the same letter are not significantly different according to Tukey's ( $\alpha=0.05$ significance level).

TABLE 5. Dry weight of weeds and yield of rhizoma perennial peanut after two years of establishment at Juana Díaz, Puerto Rico, on 2005.

\begin{tabular}{lcrrr}
\hline & & \multicolumn{3}{c}{ Dry matter } \\
\cline { 3 - 5 } Herbicide Treatment & $\begin{array}{c}\text { Rate } \\
\mathrm{kg} \text { ai/ha }\end{array}$ & $\begin{array}{c}\text { Weeds }^{1} \\
\mathrm{~g} / \mathrm{m}^{2}\end{array}$ & \multicolumn{2}{c}{$\begin{array}{c}\text { Perennial peanut } \\
\mathrm{g} / \mathrm{m}^{2}\end{array}$} \\
\hline & & & $7 \mathrm{WAL}^{2}$ & $13 \mathrm{WAL}$ \\
\cline { 3 - 5 } & & & $510 \mathrm{a}$ & $826 \mathrm{a}$ \\
Imazethapyr PRE & & & $308 \mathrm{~b}$ & $290 \mathrm{~b}$ \\
Imazethapyr - early POE & 0.07 & $211 \mathrm{~b}$ & $307 \mathrm{a}$ & $1002 \mathrm{a}$ \\
Dimethenamid PRE & 1.68 & $57 \mathrm{a}$ & $720 \mathrm{a}$ & $998 \mathrm{a}$ \\
Dimethenamid PRE & 3.36 & $92 \mathrm{a}$ & $539 \mathrm{a}$ & \\
\hline
\end{tabular}

${ }^{1}$ Broadleaves: Wild bush bean (Macroptilium lathyroides), wild poinsettia (Euphorbia heterophylla), common purslane (Portulaca oleracea), horse purslane (Thrianthema portulacastrum), spurge (Chamaesyce spp.), wire weed (Sida acuta), gale of the wind (Phylanthus niruri), morning glory (Ipomoea tiliaceae), sensitive plant (Mimosa pudica), sowthistle (Sonchus oleraceous), Galinsoga spp., small spider flower (Cleome gynandra), nutsedges (Cyperus spp.); Grasses: jungle rice (Echinochloa colona), large crabgrass (Digitaria sanguinalis), goosegrass (Eleusine indica) and itchgrass (Rottboellia cochichinensis)

${ }^{2} \mathrm{WAL}=$ weeks after leveling cut

${ }^{3} \mathrm{PRE}=$ preemergence; early $\mathrm{POE}=$ early postemergence

${ }^{4}$ Means within a column followed by the same letter are not significantly different according to Tukey's ( $\alpha=0.05$ significance level).

higher than at 26 and 52 WAH (Tables 2 and 5). At both 7 WAL and 13 WAL the lowest yield was obtained when imazethapyr was applied early POE. According to Ruiz and collaborators (2000), season has a 
marked effect on dry matter yield of rhizoma perennial peanut. They obtained the highest yield during summer.

Results of these experiments show the potential for the use of herbicides in the establishment of rhizoma perennial peanut. Ruiz et al. (2000), Valencia et al. (1999), and Venuto et al. (2000) observed high yield of the rhizoma perennial peanut when appropriate irrigation and weed management practices were used. Management practices must be employed to offset the slow establishment rate of rhizoma perennial peanut (Venuto et al., 2000). Overall, taking into account all rates and dates of herbicide applications, the best weed control was obtained with the early application dates.

\section{LITERATURE CITED}

Butler, T. J., W. R. Ocumpaugh, M. A. Sanderson, R. L. Reed and J. P. Muir, 2006. Evaluation of rhizoma peanut genotypes for adaptation in Texas. Agron. J. 98:1589-1593.

Canudas, E. G., K. H. Quesenberry, L. E. Sollenberguer and G. M. Prine, 1989. Establishment of two cultivars of rhizome peanut as affected by weed control and planting rate. Trop. Grasslands 23(3):162-170.

Canudas, E. G., K. H. Quesenberry, D. H. Teem and G. M. Prine, 1984. Sethoxydim and Dalapon application to rhizomes for common bermudagrass control in rhizome peanut. Soil Crop Sci. Soc. Fl. Proc. 43:174 -177.

Dahmer, M. L., 1995. Tech update on pursuit herbicide on alfalfa. Am. Cyanamid Co., Parsippany, N.J.

French, E. C., G. M. Prine and A. R. Blount, 2001. Perennial peanut: An alternative forage of growing importance. Extension Series. SS-AGR-39. University of Florida. IFAS

Jordan, D. L., 2007. Weed management in peanuts. Pages 47-71. In: Production guide in peanut. NCCES Annual Prod. Guide.

Ruiz, T. M., M. de L. Lugo-Torres, A. Sotomayor-Ríos, R. Ramos-Santana, E. Valencia and D. Sotomayor-Ramírez, 2007. Release of 'Henorico' rhizome perennial peanut (Arachis glabrata Benth.). J.Agric. Univ. P.R. 91(1-2):81-85.

Ruiz, T. M., R. Ramos-Santana and A. Sotomayor-Ríos, 2000. Establishment of rhizoma perennial peanut (Arachis glabrata) under irrigation at two semiarid sites in the Caribbean. J.Agric. Univ. P. R. 84:105-114.

Ruiz, T. M., R. Ramos-Santana and A. Sotomayor-Ríos, 2000. Dry matter of rhizoma perennial peanut (Arachis glabrata) harvested at six, nine, and 12 weeks at two semiarid sites. J. Agric. Univ. P. R. 84:115-132.

Valencia, E., A. Sotomayor-Ríos and S. Torres-Cardona, 1997. Establishment and effect of cutting interval on yield and nutritive value of rhizoma perennial peanut in northwestern Puerto Rico. J. Agric. Univ. P. R. 81:19-30.

Valencia, E., M. J. Williams and L. E. Sollenberger, 1999. Yield and botanical composition of rhizoma peanut-grass swards treated with herbicides. Agron. J. 91:956-961.

Venuto, B. C., W. Elkins and D. Redfearn, 2000. Soil fertility on growth and nutrient uptake of rhizome peanut. J. Plant Nutrition 23(2):231-241.

Zollinger, R. K. and D. W. Meyer, 1996. Imazethapyr for weed control in alfalfa establishment. Proc. West. Soc. Weed Sci. 49:19-21. 
